\author{
RICHARD D. PORTER \\ THOMAS D. SIMPSON
}

EILEEN MAUSKOPF

Staff, Board of Governors of the Federal Reserve System

\title{
Financial Innovation and the Monetary Aggregates
}

THE MOST RECENT WEAKNESS in the monetary aggregates has reopened basic questions about the stance of monetary policy. The pattern of markedly slow rates of growth has been especially evident in $\mathbf{M}_{1}$. In the six quarters preceding 1978:4, $M_{1}$ grew at an average annual rate of nearly 8 percent, about 3 percentage points below the growth rate of nominal GNP. But in that fourth quarter, $M_{1}$ slowed to a 4.3 percent annual rate, while GNP expanded at a 15.6 percent rate; moreover, in 1979:1, $\mathrm{M}_{1}$ declined, while nominal GNP expanded at a 9.5 percent annual rate.

There are striking similarities between the behavior of $M_{1}$ in recent months and the prolonged weakness in this aggregate from mid-1974 to early 1977. In both periods, $M_{1}$ grew at a much slower rate than that predicted using historical relationships among $\mathrm{M}_{1}$, GNP, and interest rates. This weakness can be seen in table 1, which shows predicted and actual levels and growth rates of $M_{1}$, based on a conventional $M_{1}$ demand equation. From the period beginning in mid-1974 to $1977: 1$, the error in predicting $\mathrm{M}_{1}$ cumulated to $\$ 34$ billion as the actual annual growth rate of $\mathrm{M}_{1}$ averaged about 3.5 percentage points less than that predicted. From 1978:3 to $1979: 1$, the $\mathbf{M}_{1}$ error grew by $\$ 15$ billion, as the actual $\mathbf{M}_{1}$ growth rate averaged almost 7.5 percentage points less than that predicted.

In each of these periods of unusually slow money growth, legislative

Note: The views expressed in this paper do not necessarily agree with those of the Board of Governors. We want to thank Steven H. Axilrod, Jared J. Enzler, Edward C. Ettin, John H. Kalchbrenner, Kenneth J. Kopecky, David E. Lindsey, and members of the Brookings panel for their comments. 
Table 1. Actual and Predicted Values and Errors from a Dynamic Simulation of an $M_{1}$ Demand Equation, 1974:3-1979:1

\begin{tabular}{|c|c|c|c|c|c|c|c|}
\hline \multirow{3}{*}{$\begin{array}{l}\text { Year and } \\
\text { quarter, and } \\
\text { summary } \\
\text { statistic }\end{array}$} & \multirow{2}{*}{\multicolumn{3}{|c|}{$\begin{array}{c}\text { Annualized rate of growth } \\
\text { (percent or percentage points) }\end{array}$}} & \multicolumn{4}{|c|}{ Level (billions of dollars or percent) } \\
\hline & & & & \multirow[b]{2}{*}{ Actual } & \multirow[b]{2}{*}{$\begin{array}{c}\text { Pre- } \\
\text { dicted }\end{array}$} & \multirow[b]{2}{*}{$\begin{array}{l}\text { Cumulative } \\
\text { error }\end{array}$} & \multirow{2}{*}{$\begin{array}{c}\text { Cumulative } \\
\text { percentage } \\
\text { error }^{\mathrm{a}}\end{array}$} \\
\hline & Actual & $\begin{array}{c}\text { Pre- } \\
\text { dicted }\end{array}$ & Error & & & & \\
\hline \multicolumn{8}{|c|}{ Year and quarter } \\
\hline $\begin{array}{r}1974: 3 \\
4\end{array}$ & $\begin{array}{l}4.0 \\
4.6\end{array}$ & $\begin{array}{l}7.9 \\
8.6\end{array}$ & $\begin{array}{l}-4.0 \\
-4.0\end{array}$ & $\begin{array}{l}279.0 \\
282.1\end{array}$ & $\begin{array}{l}284.0 \\
290.1\end{array}$ & $\begin{array}{l}-5.0 \\
-8.0\end{array}$ & $\begin{array}{l}-1.8 \\
-2.8\end{array}$ \\
\hline $\begin{array}{r}1975: 1 \\
2 \\
3 \\
4\end{array}$ & $\begin{array}{l}2.1 \\
5.7 \\
7.3 \\
3.0\end{array}$ & $\begin{array}{l}8.5 \\
8.9 \\
9.2 \\
9.2\end{array}$ & $\begin{array}{l}-6.4 \\
-3.2 \\
-1.9 \\
-6.2\end{array}$ & $\begin{array}{l}283.6 \\
287.7 \\
292.9 \\
295.1\end{array}$ & $\begin{array}{l}296.3 \\
302.9 \\
309.9 \\
317.0\end{array}$ & $\begin{array}{l}-12.6 \\
-15.2 \\
-16.9 \\
-21.9\end{array}$ & $\begin{array}{l}-4.5 \\
-5.3 \\
-5.8 \\
-7.4\end{array}$ \\
\hline $\begin{array}{r}1976: 1 \\
2 \\
3 \\
4\end{array}$ & $\begin{array}{l}4.6 \\
6.4 \\
4.2 \\
7.4\end{array}$ & $\begin{array}{l}9.6 \\
8.6 \\
7.8 \\
8.0\end{array}$ & $\begin{array}{l}-5.1 \\
-2.2 \\
-3.6 \\
-0.5\end{array}$ & $\begin{array}{l}298.5 \\
303.3 \\
306.5 \\
312.1\end{array}$ & $\begin{array}{l}324.6 \\
331.6 \\
338.1 \\
344.8\end{array}$ & $\begin{array}{l}-26.1 \\
-28.3 \\
-31.6 \\
-32.7\end{array}$ & $\begin{array}{r}-8.8 \\
-9.3 \\
-10.3 \\
-10.5\end{array}$ \\
\hline $\begin{array}{r}1977: 1 \\
2 \\
3 \\
4\end{array}$ & $\begin{array}{l}7.4 \\
7.4 \\
8.7 \\
7.4\end{array}$ & $\begin{array}{l}8.6 \\
9.0 \\
8.2 \\
7.4\end{array}$ & $\begin{array}{r}-1.2 \\
-1.6 \\
0.5 \\
-0.0\end{array}$ & $\begin{array}{l}317.9 \\
323.8 \\
330.8 \\
336.9\end{array}$ & $\begin{array}{l}352.2 \\
360.1 \\
367.5 \\
374.3\end{array}$ & $\begin{array}{l}-34.3 \\
-36.3 \\
-36.7 \\
-37.4\end{array}$ & $\begin{array}{l}-10.8 \\
-11.2 \\
-11.1 \\
-11.1\end{array}$ \\
\hline $\begin{array}{r}1978: 1 \\
2 \\
3 \\
4\end{array}$ & $\begin{array}{l}6.7 \\
9.2 \\
8.2 \\
4.3\end{array}$ & $\begin{array}{l}7.0 \\
9.4 \\
8.5 \\
8.6\end{array}$ & $\begin{array}{l}-0.3 \\
-0.2 \\
-0.3 \\
-4.3\end{array}$ & $\begin{array}{l}342.5 \\
350.4 \\
357.5 \\
361.4\end{array}$ & $\begin{array}{l}380.8 \\
389.7 \\
398.0 \\
406.5\end{array}$ & $\begin{array}{l}-38.3 \\
-39.4 \\
-40.5 \\
-45.1\end{array}$ & $\begin{array}{l}-11.2 \\
-11.2 \\
-11.3 \\
-12.5\end{array}$ \\
\hline $1979: 1$ & -2.4 & 8.2 & -10.6 & 359.2 & 414.9 & -55.7 & -15.5 \\
\hline \multicolumn{8}{|c|}{ Summary statistic } \\
\hline $\begin{array}{l}\text { Mean error } \\
\text { Mean absolu } \\
\text { Root-mean-s }\end{array}$ & $\begin{array}{l}\text { te error } \\
\text { square err }\end{array}$ & & $\begin{array}{r}-2.9 \\
3.0 \\
4.0\end{array}$ & & & $\begin{array}{r}-29.6 \\
29.6 \\
32.3\end{array}$ & \\
\hline
\end{tabular}

Sources: Actual values are from the Board of Governors of the Federal Reserve System. Predicted values are from a dynamic simulation of the $M_{1}$ equation in the appendix, table A-1. This equation uses the same specification and sample period (1960:4 to 1974:2) as the equation for $\mathbf{M}_{1}$ reported in "A Proposal for Redefining Monetary Aggregates," Federal Reserve Bulletin, vol. 65 (January 1979), p. 26. Figures are rounded.

a. Cumulative error as a percent of actual level.

and regulatory changes have created new kinds of deposits or permitted expanded use of existing ones, contributing to some substitution of other financial assets for $M_{1}$. The recent weakness in $M_{1}$ has coincided with the introduction of automatic transfer services (ATS) in November 1978. ATS has encouraged the shifting of funds from demand-deposit accounts to savings accounts. During the earlier period of weak $\mathrm{M}_{1}$ growth, negotiable-orders-of-withdrawal (NOW) accounts at commercial banks and 
thrift institutions in New England and share drafts from credit unions emerged, providing individuals with an explicit return on checkable balances. In addition, commercial banks were authorized to offer savings accounts to domestic government units in November 1974 and to businesses in November 1975. Such new accounts encouraged some deposit holders to shift funds from demand-deposit accounts. However, Board staff estimates indicate that such developments can explain no more than one-fourth of the estimated shortfall in $\mathrm{M}_{1}$ growth shown in table 1 during the earlier period, and that ATS can explain only about one-fourth of the weakness during the most recent period. ${ }^{1}$ Furthermore, technical explanations that are sometimes suggested, such as growth in Federal Reserve float, do not account for much, if any, of the weakness. ${ }^{2}$

Finally, table 2 confirms that, during each period of weakness in $\mathbf{M}_{1}$, sizable forecast errors also emerged in $\mathrm{M}_{2}$. Table 2 shows that, by early 1977 , the cumulative overprediction from a standard $M_{2}$ equation slightly exceeded the $\$ 34$ billion overprediction of $M_{1}$. Since 1978:3, the level of the $\mathrm{M}_{2}$ error increased by almost twice as much as the $\mathrm{M}_{1}$ error. Thus the weak growth in $\mathrm{M}_{1}$ cannot be explained by the substitution of savings and time deposits for demand deposits. ${ }^{3}$

It is important to note that, in both periods, weakness in the aggregates emerged at a time when short-term interest rates were at historically high levels. Meanwhile, other financial instruments-security repurchase agreements (RPs) and money-market mutual funds-apparently became more widely used as deposit substitutes. In the next section the analysis focuses on the relationship between high interest rates, the weakness in monetary aggregates, and the role of these new instruments.

\section{The Cash-Management Process}

Much of the weakness in demand deposits relative to GNP in recent years has been in the deposit holdings of nonfinancial corporations, which

1. Board staff estimates suggest that the introduction of ATS accounts nationwide and NOW accounts in New York depressed $M_{1}$ growth by about 1 percentage point at an annual rate in 1978:4 and by nearly 3 percentage points in 1979:1.

2. From $1978: 4$ to early 1979 , Federal Reserve float became large (but recently it has returned to a more normal level), while $M_{1}$ was virtually unchanged during this period.

3. The weakness in $\mathrm{M}_{1}$ has been entirely attributable to the demand-deposit component; forecasts of currency have continued to be accurate. 
Table 2. Actual and Predicted Values and Errors from a Dynamic Simulation of an $M_{2}$ Demand Equation, 1974:3-1979:1

\begin{tabular}{|c|c|c|c|c|c|c|c|}
\hline \multirow{3}{*}{$\begin{array}{l}\text { Year and } \\
\text { quarter, and } \\
\text { summary } \\
\text { statistic }\end{array}$} & \multirow{2}{*}{\multicolumn{3}{|c|}{$\begin{array}{l}\text { Annualized rate of growth } \\
\text { (percent or percentage points) }\end{array}$}} & \multicolumn{4}{|c|}{ Level (billions of dollars or percent) } \\
\hline & & & & \multirow[b]{2}{*}{ Actual } & \multirow[b]{2}{*}{$\begin{array}{r}\text { Pre- } \\
\text { dicted }\end{array}$} & \multirow[b]{2}{*}{$\begin{array}{c}\text { Cumulative } \\
\text { error }\end{array}$} & \multirow{2}{*}{$\begin{array}{c}\text { Cumulative } \\
\text { percentage } \\
\text { error }^{\mathbf{2}}\end{array}$} \\
\hline & Actual & $\begin{array}{l}\text { Pre- } \\
\text { dicted }\end{array}$ & Error & & & & \\
\hline \multicolumn{8}{|c|}{ Year and quarter } \\
\hline $\begin{array}{r}1974: 3 \\
4\end{array}$ & $\begin{array}{l}6.1 \\
6.6\end{array}$ & $\begin{array}{l}7.6 \\
8.2\end{array}$ & $\begin{array}{l}-1.5 \\
-1.6\end{array}$ & $\begin{array}{l}599.9 \\
609.8\end{array}$ & $\begin{array}{l}604.1 \\
616.5\end{array}$ & $\begin{array}{l}-4.2 \\
-6.7\end{array}$ & $\begin{array}{l}-0.7 \\
-1.1\end{array}$ \\
\hline $\begin{array}{r}1975: 1 \\
2 \\
3 \\
4\end{array}$ & $\begin{array}{r}6.4 \\
9.5 \\
10.0 \\
6.8\end{array}$ & $\begin{array}{r}9.5 \\
10.6 \\
9.9 \\
11.0\end{array}$ & $\begin{array}{r}-3.0 \\
-1.1 \\
0.1 \\
-4.2\end{array}$ & $\begin{array}{l}619.6 \\
634.3 \\
650.2 \\
661.2\end{array}$ & $\begin{array}{l}631.1 \\
647.9 \\
664.0 \\
682.2\end{array}$ & $\begin{array}{l}-11.5 \\
-13.5 \\
-13.8 \\
-21.0\end{array}$ & $\begin{array}{l}-1.9 \\
-2.1 \\
-2.1 \\
-3.2\end{array}$ \\
\hline $\begin{array}{r}1976: 1 \\
2 \\
3 \\
4\end{array}$ & $\begin{array}{r}10.5 \\
10.0 \\
8.8 \\
12.6\end{array}$ & $\begin{array}{l}13.0 \\
11.7 \\
10.9 \\
11.7\end{array}$ & $\begin{array}{r}-2.5 \\
-1.7 \\
-2.1 \\
0.9\end{array}$ & $\begin{array}{l}678.6 \\
695.5 \\
710.9 \\
733.3\end{array}$ & $\begin{array}{l}704.3 \\
724.9 \\
744.7 \\
766.4\end{array}$ & $\begin{array}{l}-25.7 \\
-29.3 \\
-33.8 \\
-33.1\end{array}$ & $\begin{array}{l}-3.8 \\
-4.2 \\
-4.8 \\
-4.5\end{array}$ \\
\hline $\begin{array}{r}1977: 1 \\
2 \\
3 \\
4\end{array}$ & $\begin{array}{r}10.9 \\
9.0 \\
10.0 \\
7.9\end{array}$ & $\begin{array}{r}12.2 \\
12.1 \\
10.6 \\
9.2\end{array}$ & $\begin{array}{l}-1.2 \\
-3.1 \\
-0.6 \\
-1.3\end{array}$ & $\begin{array}{l}753.3 \\
770.3 \\
789.6 \\
805.3\end{array}$ & $\begin{array}{l}789.7 \\
813.6 \\
835.1 \\
854.3\end{array}$ & $\begin{array}{l}-36.4 \\
-43.3 \\
-45.5 \\
-49.0\end{array}$ & $\begin{array}{l}-4.8 \\
-5.6 \\
-5.8 \\
-6.1\end{array}$ \\
\hline $\begin{array}{r}1978: 1 \\
2 \\
3 \\
4\end{array}$ & $\begin{array}{l}7.0 \\
8.4 \\
9.9 \\
7.7\end{array}$ & $\begin{array}{r}8.4 \\
10.3 \\
10.3 \\
10.3\end{array}$ & $\begin{array}{l}-1.4 \\
-1.9 \\
-0.5 \\
-2.6\end{array}$ & $\begin{array}{l}819.3 \\
836.6 \\
857.3 \\
873.9\end{array}$ & $\begin{array}{l}872.3 \\
894.7 \\
917.9 \\
941.6\end{array}$ & $\begin{array}{l}-53.0 \\
-58.2 \\
-60.6 \\
-67.8\end{array}$ & $\begin{array}{l}-6.5 \\
-7.0 \\
-7.1 \\
-7.8\end{array}$ \\
\hline $1979: 1$ & 1.6 & 9.8 & -8.2 & 877.4 & 964.8 & -87.3 & -10.0 \\
\hline \multicolumn{8}{|c|}{ Summary statistic } \\
\hline $\begin{array}{l}\text { Mean error } \\
\text { Mean absol } \\
\text { Root-mean- }\end{array}$ & $\begin{array}{l}\text { ute error } \\
\text { square erro }\end{array}$ & & $\begin{array}{r}-2.0 \\
2.1 \\
2.7\end{array}$ & & & $\begin{array}{r}-36.5 \\
36.5 \\
42.6\end{array}$ & \\
\hline
\end{tabular}

Sources: Same as table 1, but using the $\mathrm{M}_{2}$ equation. Figures are rounded. a. Cumulative error as a percent of actual level.

also became major lenders of RP funds. ${ }^{4}$ While it is tempting to conclude that weakness in $M_{1}$ simply reflects the substitution of such liquid assets

4. For econometric evidence see, for example, Helen T. Farr, Richard D. Porter, and Eleanor M. Pruitt, "Demand Deposit Ownership Survey," in Improving the Monetary Aggregates: Staff Papers (Board of Governors of the Federal Reserve System, 1978), pp. 91-116. Also note that from 1970:2 to 1978:4 the ratio of personal income to gross demand deposits of consumers increased by 16.5 percent, while the ratio of total business sales to gross demand deposits of nonfinancial businesses increased by 49.4 percent. 
for demand deposits, it is our view that these developments are part of a general process of intensified cash management.

Several developments lie behind this more intensive cash management. During the 1970s it has become less costly for corporate cash managers to invest excess demand balances in the money market. The cost of moving funds from accounts with local or regional banks to a money-market asset has fallen in real terms. Improved information systems and forecasting procedures have been introduced, which reduce uncertainties regarding near-term cash flows and thereby permit profitable reductions in demanddeposit balances. Moreover, high market rates of interest in 1973-74, 1978 , and early 1979 have increased the incentive for managers to implement new cash-management techniques. Reports indicate that large corporations began to modify their cash-management procedures starting about 1973 and that many smaller corporations have begun to utilize the newer techniques during the past two years.

These developments can be readily interpreted within the established inventory theory of the demand for money by firms. ${ }^{5}$ Given the uncertainty about day-to-day cash flows, deposit holdings, $m$, will be positively related to the transactions costs, $t$, of exchanging deposits for interest-bearing assets and to the standard deviation of net cash flows, $\sigma$, and negatively related to the opportunity costs of holding cash, $r .^{6}$ By purchasing cashmanagement services to reduce uncertainty about cash flows, a firm may lower its overall inventory costs-the sum of expected transactions costs, the opportunity costs of expected cash balances, and cash-management costs. ${ }^{7}$ When this activity is profitable, average deposit holdings are reduced. Moreover, as short-term interest rates rise, there is a greater incentive to increase the use of cash-management activities so that the demand for money becomes more interest-elastic at higher interest rates. ${ }^{8}$ Indeed,

5. See, for example, Merton $H$. Miller and Daniel Orr, "A Model of the Demand for Money by Firms," Quarterly Journal of Economics, vol. 80 (August 1966), pp. 413-35.

6. More specifically, in the Miller-Orr model, expected cash holdings are given by

$$
\frac{4}{3}\left(\frac{3 t \sigma^{2}}{4 r}\right)^{1 / 3}
$$

7. See Richard D. Porter and Eileen Mauskopf, "Cash Management and the Recent Shift in the Demand for Demand Deposits" (Board of Governors of the Federal Reserve System, Division of Research and Statistics, n.d.).

8. Ibid., pp. 34-36. 
it appears that industry cost-benefit ratios for evaluating such activities depend explicitly on the level of short-term rates.

A variety of cash-management techniques (for example, lock boxes, control disbursement, payable-through drafts, forecasting models, and information retrieval systems) has improved information about near-term cash flows. From interviews with corporate cash managers and bankers, it appears that one of the most popular techniques currently in use is control disbursement. This technique increases the information that a firm has at the time investment decisions are made about expected clearings against its account. As a result, the firm can reduce the amount of balances that it holds to meet any unexpected outflows from its account. ${ }^{9}$ On the receipts side, lock boxes serve a similar function by increasing certainty about near-term collected balances. ${ }^{10}$

Another cash-management technique that has contributed to the weakness in demand deposits is the cash-concentration account, which permits the customer to exploit economies of scale that arise from operating one account rather than many scattered accounts. Using wire transfers and depository transfer checks, the firm can consolidate receipts into a single concentration account from which it funds disbursements. Abstracting from the costs of consolidating accounts, it can be shown that the optimal

9. In control disbursement, the firm typically maintains a zero or fixed balance account at a "remote" bank which, because of its location, receives only one cash letter from the Federal Reserve early each day. When the information in the cash letter is sorted, the corporation is notified of the exact amount of funds needed to cover all clearings against its account that day. The information comes early enough in the day, usually by noon, so that a more accurate determination can be made of funds available for investment. Checking accounts at other "nonremote" banks usually are such that the firm will not know until late that day, or sometimes even until the next day, the amount of funds needed for clearing. This is because other banks may receive checks for clearing throughout the day by picking up cash letters at Federal Reserve offices or through direct sends.

10. The bank operating the lock box can notify the corporation daily (or more often) when items received at the lock box become collected balances. There are two distinct effects associated with the use of lock boxes and control disbursement: information is received about cash flows and the timing of receipts and clearings is altered. Lock boxes and control disbursement were initially marketed and utilized for the latter ("float") purpose. The gains from these activities may be quite large, and for some firms they are probably much larger than the gains from any reduction in uncertainty about cash flow. However, it appears that most firms have increasingly realized the value of the accompanying information gains. Moreover, it has become clear that such information gains can easily exceed the "float" gains for firms with large variations in daily clearings or collections. 
amount of cash in the concentration account is always less than the optimal cash balance held when separate accounts are maintained, even when net receipts in the different accounts are perfectly correlated. However, when costs are associated with consolidating funds, the decision of whether to concentrate accounts depends on the costs of concentrating relative to the gains. Tending to lower the consolidation costs are the reduced personnel and management costs of operating only one account and the advantage of spreading any fixed brokerage fee over more investment dollars. Because the gains from consolidation increase with the rate of interest, there is more incentive to concentrate when interest rates are high.

Coinciding with the increased use of cash-management techniques has been the growing volume of very short-term liquid assets such as RPs and money-market mutual funds. In fact, many have argued that recent periods of weakness in demand deposits can be traced mainly to the growth in RPs and to money-market mutual funds. ${ }^{11}$

The arguments attributing the weakness in $M_{1}$ to the growth in these short-term liquid assets must be interpreted carefully. The traditional theory of money demand is built around the notion that changes in the yield on an interest-bearing asset or changes in the cost of converting interest-bearing assets into money will affect money holdings. Since RPs have lower transactions costs than many other assets of comparable yields, their introduction and incorporation into cash-management strategies might be expected to reduce the volume of demand deposits held at any given interest rate. But what is sometimes argued is that the demand for money has not really changed, but instead is being incorrectly mea-

11. See P. A. Tinsley, B. Garrett, and M. E. Friar, "The Measurement of Money Demand" (Board of Governors of the Federal Reserve System, Special Studies Section, November 1978); Gillian Garcia and Simon Pak, "Some Clues in the Case of the Missing Money," American Economic Review, vol. 69 (May 1979, Papers and Proceedings, 1978), pp. 330-34; and John Wenninger and Charles Sivesind, "Changing the M1 Definition: An Empirical Investigation" (Federal Reserve Bank of New York, April 1979).

The recent growth of money-market mutual funds is impressive. Such funds have grown from about $\$ 8.1$ billion at the end of September 1978 to about $\$ 18.2$ billion in early April. Since these accounts have low brokerage fees, high overnight yields, and are checkable, it is conceivable that two-thirds of the increase in the $\mathbf{M}_{1}$ error in the recent period can be assigned to this source. That is, suppose the $\$ 10$ billion increase in these funds comes only at the expense of household and corporate demand-depøsit balances. Because of the economies of scale involved in pooling receipts and disbursements, the mutual funds surely hold less than $\$ 1$ billion in demand deposits. 
sured. By including RPs in the narrowest monetary aggregate, no weakness in this aggregate would emerge because the sum of $M_{1}$ plus RPs would behave as $M_{1}$ alone did previously. ${ }^{12}$ This argument implies that RPs dominate demand deposits by some agents. ${ }^{13}$

In the case of money-market funds, the question of transactions costs is moot. Accounts containing such funds are typically checkable; and for most funds no charges are made for drafts, provided that checks exceed a minimum amount. ${ }^{14}$ The checkability feature and the near-market yield on money-market funds make them attractive relative to demand deposits.

If RPs and money-market mutual funds tend to dominate money, then the stability of the $M_{1}$ demand equations might indeed be restored by adding RPs or RPs and money-market mutual funds to $M_{1}$. Table 3 provides the simulation results for a demand equation using an $\mathrm{M}_{1}$ specification but estimated for the sum of $M_{1}$ plus RPs at commercial banks, and for the sum of $M_{1}, R P s$, and money-market mutual funds. The table indicates that the addition of RPs can cut the demand error appreciably. At the end of 1975 the cumulative errors in both the equation for $M_{1}$ (table 1 ) and the equation for the sum of $M_{1}$ and RPs (table 3) were about $\$ 20$ billion. From 1975:4 to 1978:3, the $M_{1}$ level error doubled in size, while the error in the equation containing RPs increased by about half. Most recently, from 1978:3 to 1979:1, the $\mathrm{M}_{1}$ error increased by an additional $\$ 15$ billion, at a time when the error for the sum of $M_{1}$ and RPs grew by $\$ 10$ billion. A better performance was shown by the broader aggregate, $M_{1}, R P s$, and money-market mutual funds. The table shows that since 1976:1, the equation for this money measure has predicted quite accurately.

Should we conclude from this evidence that RPs and money-market

12. This argument is set forth in Garcia and Pak, "Some Clues in the Case of the Missing Money."

13. To be a dominant asset, the RP market must be active late in the day when firms know the amount of demand balances needed to cover net disbursements. Alternatively, if the market closes earlier in the day, the returns on an RP must be large enough to cover potential overdraft charges or the penalty for breaking an RP commitment.

14. The checkability of money-market funds is limited to some extent by the typical requirement that checks must exceed $\$ 500$. However, the average size of checks written at commercial banks is roughly $\$ 500$. See "Check Processing at Federal Reserve Offices," Federal Reserve Bulletin, vol. 65 (February 1979), p. 99. Other Board staff estimates suggest that about 10 percent of all checks written have face amounts of $\$ 500$ or larger. 
Table 3. Errors from a Dynamic Simulation of a Money-Demand Equation for Alternative Measures of Money, 1974:3-1979:1

\begin{tabular}{|c|c|c|c|c|}
\hline \multirow{3}{*}{$\begin{array}{l}\text { Year and } \\
\text { quarter, and } \\
\text { summary } \\
\text { statistic }\end{array}$} & \multicolumn{4}{|c|}{ Cumulative error } \\
\hline & \multicolumn{2}{|c|}{$M_{1}$ and $R P s$} & \multicolumn{2}{|c|}{$\begin{array}{c}M_{1}, R P s, \text { and money-market } \\
\text { mutual funds }\end{array}$} \\
\hline & $\begin{array}{l}\text { Billions of } \\
\text { dollars }\end{array}$ & Percent ${ }^{\mathrm{a}}$ & $\begin{array}{l}\text { Billions of } \\
\text { dollars }\end{array}$ & Percent $t^{\mathrm{a}}$ \\
\hline \multicolumn{5}{|l|}{ Year and quarter } \\
\hline $\begin{array}{r}1974: 3 \\
4\end{array}$ & $\begin{array}{l}-6.2 \\
-8.8\end{array}$ & $\begin{array}{l}-2.1 \\
-3.0\end{array}$ & $\begin{array}{l}-5.7 \\
-7.4\end{array}$ & $\begin{array}{l}-1.9 \\
-2.5\end{array}$ \\
\hline $\begin{array}{r}1975: 1 \\
2 \\
3 \\
4\end{array}$ & $\begin{array}{l}-14.1 \\
-15.7 \\
-15.7 \\
-20.0\end{array}$ & $\begin{array}{l}-4.7 \\
-5.2 \\
-5.1 \\
-6.5\end{array}$ & $\begin{array}{l}-11.4 \\
-12.3 \\
-12.5 \\
-16.9\end{array}$ & $\begin{array}{l}-3.8 \\
-4.0 \\
-4.0 \\
-5.4\end{array}$ \\
\hline $\begin{array}{r}1976: 1 \\
2 \\
3 \\
4\end{array}$ & $\begin{array}{l}-23.3 \\
-23.1 \\
-24.4 \\
-24.5\end{array}$ & $\begin{array}{l}-7.4 \\
-7.1 \\
-7.4 \\
-7.3\end{array}$ & $\begin{array}{l}-20.0 \\
-19.9 \\
-21.5 \\
-21.4\end{array}$ & $\begin{array}{l}-6.3 \\
-6.1 \\
-6.4 \\
-6.3\end{array}$ \\
\hline $\begin{array}{r}1977: 1 \\
2 \\
3 \\
4\end{array}$ & $\begin{array}{l}-26.6 \\
-27.7 \\
-26.6 \\
-25.2\end{array}$ & $\begin{array}{l}-7.7 \\
-7.9 \\
-7.4 \\
-6.8\end{array}$ & $\begin{array}{l}-23.3 \\
-24.7 \\
-23.8 \\
-22.1\end{array}$ & $\begin{array}{l}-6.7 \\
-6.9 \\
-6.5 \\
-5.9\end{array}$ \\
\hline $\begin{array}{r}1978: 1 \\
2 \\
3 \\
4\end{array}$ & $\begin{array}{l}-25.7 \\
-28.4 \\
-28.6 \\
-29.5\end{array}$ & $\begin{array}{l}-6.8 \\
-7.4 \\
-7.3 \\
-7.3\end{array}$ & $\begin{array}{l}-21.7 \\
-22.9 \\
-21.7 \\
-21.0\end{array}$ & $\begin{array}{l}-5.7 \\
-5.9 \\
-5.4 \\
-5.1\end{array}$ \\
\hline $1979: 1$ & -38.8 & -9.7 & -25.2 & -6.1 \\
\hline \multicolumn{5}{|l|}{ Summary statistic } \\
\hline Mean error & -22.8 & & -18.7 & \\
\hline Mean absolute error & 22.8 & & 18.7 & \\
\hline $\begin{array}{l}\text { Root-mean-square } \\
\text { error }\end{array}$ & 24.0 & & 19.6 & \\
\hline
\end{tabular}

Sources: Same as table 1, but using the equation for the sum of $\mathrm{M}_{1}$ and security repurchase agreements at banks (RPs) and the equation for the sum of $M_{1}, R P s$, and money-market mutual funds. Those equations use the same specification as the $M_{1}$ equation in the appendix, table A-1. The RP data used here are preliminary and are under review by the Board staff. The RP series is believed to contain considerably more estimation error than the money stock figures. Moreover, RP estimates for 1978:4 to 1979:1 are based on September 1978 call report relationships and are likely to be revised, perhaps substantially, as some recent call reports information becomes available.

a. Cumulative error as a percent of actual level. 
mutual funds, taken together, explain the $\mathrm{M}_{1}$ puzzle? In the early period from mid-1974 to early 1976, they clearly do not help much, although more recently they help considerably. However, results in table 3 are misleading insofar as part of the growth in RPs and money-market funds should be related to the increase in their own yields over this period. If these equations were respecified to include the appropriate own rates, we expect the predicted values would be higher and the errors would be larger. ${ }^{15}$ Put differently, in the most recent period, how can we be sure that growth in money-market mutual funds or RPs has not come at the expense of time and savings deposits as well as demand deposits? ${ }^{16}$

The econometric evidence indicating that RPs can only account for a portion of the $M_{1}$ shortfall is reinforced by some features of the RP market. It is difficult to substantiate the allegation that firms can convert demand deposits into RPs at the end of the day when they have perfect certainty about their cash flow. Reports based on interviews suggest that the volume of RPs negotiated late in the day is small. Similarly, alleged arrangements in which excess demand balances are automatically invested at the end of the day in RPs appear to account for only a small fraction of RPs. In fact, most RP transactions are arranged early in the day and they are rarely allowed (by either the bank or the nonbank dealer) to be reversed at a later point in the day. Also, cash managers can choose from a variety of alternatives to commercial bank RPs having similar net returns, such as RPs with nonbank dealers, offshore dollar deposits, specially tailored commercial paper, and money-market funds. ${ }^{17}$

15. Some crude empirical work supports these assertions. When the federal funds rate (as a proxy for the own rate on RPs) was added as an independent variable to the equation for the sum of $\mathrm{M}_{1}$ and RPs, the simulation errors were somewhat higher than those given in table 3.

16. Recall that most recently the $\mathrm{M}_{2}$ error (in billions of dollars) has increased much more than has the $\mathrm{M}_{1}$ error.

17. An RP arranged with a commercial bank results in an immediate reduction in the public's demand-deposit balances, while an RP arranged with a nonbank dealer or a similar transaction with another nonbank institution does not lead to such an immediate decline in demand deposits. However, when the Federal Reserve uses the federal funds rate as the operating target, the level of deposit holdings is essentially determined by demand; in this case, the effects of these other transactions on the money supply are likely to be the same. For example, the dealer could disburse these funds by repaying a maturing RP or by acquiring securities from the nonbank public; as a result, such funds would likely return to private demand accounts. But, because the public does not want to hold these deposits, additional transactions will occur that will place downward pressure on market rates of interest. Through efforts by 
Although it might appear that money-market mutual funds have displaced demand deposits, the evidence indicates that the funds are not being used as demand deposits. To date, industry sources indicate that only about one drait per month is written on these accounts, compared with twenty-two per month on regular demand-deposit accounts. In addition, the annual turnover rate of the money-market fund obligations-that is, the dollar volume of redemptions divided by average dollar volumeappears to average only two and a half to three. This rate is substantially below the annual demand-deposit turnover rate of about one hundred for accounts at banks outside New York City and only slightly larger than the turnover rates for all passbook savings accounts at commercial banks. Finally, the typical money-market fund account is larger than the usual transactions account, averaging about $\$ 20,000$ for stockbroker and general purpose funds and about $\$ 60,000$ at funds restricted to particular institutions.

Given the institutional evidence on RPs and money funds, such investments can best be viewed as affecting $M_{1}$ through their role as buffers to demand deposits instead of as replacements for demand deposits. For many individuals, the money-market funds apparently serve as a more efficient demand-deposit buffer than do passbook savings accounts; corporations have apparently found money-market funds and, to a greater degree, RPs to be attractive buffers. An increase in the yields on these assets would thus tend to constrain $\mathrm{M}_{1}$ growth in the same way that an increase in the rate on passbook accounts would. Moreover, these instruments presumably have attracted funds from those assets that have traditionally acted as buffers in addition to drawing funds from demanddeposit balances. A properly specified demand equation for these assets therefore would probably have to include portfolio considerations in addition to transaction elements.

The above considerations are consistent with the implications of the cash-management process. Cash-management techniques permit firms to conduct a given scale of operations with smaller amounts of demand de-

the central bank to stabilize short-term rates of interest, these unwanted demand balances will tend to be removed from the system. The key issue is the length of time it takes for such demand balances to be removed. If the time is sufficiently brief, then a desire by the public to reduce its demand balances and to acquire dealer RPs will result in a reduction in demand deposits in much the same way as if the RPs are arranged with a commercial bank, even though the latter process will be more roundabout than the former. 
posits. In other words, the cash-management process results in a shift in the demand for money relative to GNP. Nevertheless, the role of RPs and money-market funds in this process is important in several ways. First, even in the absence of increasing familiarity with cash-management practices, the positive overnight yields to be earned on these assets enhance their use as a buffer to demand deposits and consequently reduce demanddeposit balances. Second, the yields increase the incentive to utilize those cash-management techniques that reduce uncertainty about near-term cash flows, thus further reducing the level of demand deposits.

\section{Incentives for Cash Management}

Technological developments and competitive forces in the market for liquid funds have contributed to reductions in the public's holdings of demand deposits relative to GNP. Computerization has facilitated the regular monitoring of cash balances and has improved the accuracy of cash-flow forecasts. Also, the growing availability and convenience of wire transfers permit funds to be transferred readily from one demanddeposit account of a firm to another or between liquid assets and demand accounts. Moreover, nonbank institutions, such as money-market mutual funds, and security dealers have intensified their efforts to attract a growing share of the public's liquid assets, as have foreign banking offices.

These developments-the increasing use of cash management and the emergence of new or more attractive liquid assets-might be viewed as a consequence of the legal prohibition of interest on demand deposits and the absence of the payment of interest on bank reserves. As a consequence, banks have devised methods of paying implicit interest on their demanddeposit balances. At large banks, compensation usually takes the form of credit services (typically lines of credit) and cash-management services. The implicit compensation rate paid on demand balances is generally tied to a money-market rate, adjusted for the proportion held as idle required reserves, and applied to collected balances in the account. ${ }^{18}$

18. Specifically, the rates on treasury bills (usually with ninety-day maturity) are used to set an "earnings credit rate." Compensating balances are then equal to the value of services divided by the earnings credit rate, where this rate is the bill rate multiplied by one minus the reserve requirement. 
These implicit rates still fall short of the competitive rate because required reserves held by member banks against their deposits do not earn interest.

If a competitive rate of interest were paid on required reserves, banks would be able to offer their customers more attractive terms. But even if interest were allowed on demand deposits and compensation were paid on required reserves, demand deposits and other near-money financial instruments would have different yields. Because demand-deposit funds can be deposited or withdrawn at any time during the business day, they have higher reserve management costs for the bank than do very short-term investments. Because of these higher reserve management costs, the rates that would be offered on demand balances would fall short of market yields on investments with very short maturities, such as RPs. ${ }^{19}$ And customers would continue to have incentives to use cash-management techniques, both to earn the higher rate on near money and to slow disbursements and speed up receipts.

\section{Interpreting the Monetary Aggregates}

The financial innovations discussed above present a number of difficulties for the interpretation of the monetary aggregates and for the conduct of monetary policy. Some of these difficulties can be reduced by changing the definitions of the monetary aggregates. Indeed, the recent proposals by the Board staff for redefining the monetary aggregates take account of important developments that have altered the deposit liabilities of depository institutions. ${ }^{20}$ The proposed $\mathrm{M}_{1}$ contains newly introduced transactions deposits, such as NOW and ATS balances. The proposed $\mathrm{M}_{2}$

19. This argument is consistent with the observation that RPs arranged early in the day generally have a higher yield than RPs placed later. If a bank or dealer held collateral until late in the day (when the customers are more certain of what their cash position will be), then on average the RP issuer would be left holding excess collateral. To offset the possibility of such a loss, the issuer would be forced to offer a lower rate on RPs placed late in the day. Reports indicate that, under the circumstances, customers prefer to receive a more favorable morning yield, thus incurring the costs of uncertainty themselves.

20. "A Proposal for Redefining the Monetary Aggregates," Federal Reserve Bulletin, vol. 65 (January 1979), pp. 13-42. 
adds to this savings deposits at all depository institutions on grounds that recent regulatory changes and competitive pressures have generally enhanced the liquidity of all savings balances. Meanwhile, the growing illiquidity of time deposits at all depository institutions has been recognized, and all such deposits have been excluded from the proposed $\mathbf{M}_{2}$ and included instead in the proposed $\mathbf{M}_{3}$. However, even these aggregates generally do not have stable demand functions.

The instability of the estimated demand functions for the proposed aggregates (and for the current aggregates) arises largely from the fundamental changes that are occurring in the nature of deposits and near money. But we believe that the shifts of the demand functions arise at least as much from the cash-management process discussed earlier. Creating an empirical framework for evaluating and predicting the impact of the cash-management process is difficult, however, for several reasons. Historical experience with the cash-management process is limited. Moreover, the incentives for continued cash management are closely tied to the existence of regulations, high interest rates, and technological and competitive developments. Thus it is quite difficult to isolate the impact of each of these factors on the demand for money.

The increasing availability of new money substitutes poses an additional problem. Some of these money substitutes, such as RPs, are offered by domestic banks; others, such as money-market funds and short-term commercial paper, are available at nonbank institutions. Eurodollars are offered by banking offices abroad-foreign banks and foreign branches of U.S. banks. One could deal with such money substitutes by including very short-term liquid investments in measures of the monetary aggregates. Thus $\mathbf{M}_{1}$-or perhaps some broader aggregate-could include the RP liabilities of commercial banks and dealers, money-market funds, Eurodollar holdings of U.S. residents, short-term commercial paper, and so forth.

While a broader money measure has some desirable attributes, it is unlikely that it would bear as close a relationship to transactions or GNP as demand deposits during those periods when the cash-management process is relatively dormant, such as the period prior to mid-1974. To the extent that the cash-management process is unpredictable, a broader measure may have some "built-in stability" because much of the funds released from demand deposits will likely be placed in such short-term buffers. However, the interest-bearing component of such a measure may often be 
dominated by motives besides transactions demand related to income. ${ }^{21}$ For example, asset holders may at times want to keep a large proportion of their financial assets in very short-term funds for portfolio reasons. Accurately predicting such movements is difficult. Furthermore, the spectrum of available liquid assets may expand so that funds could shift from those buffers included in a particular monetary aggregate to those excluded from the aggregate. ${ }^{22}$

In principle, one could separate the total volume of these buffers into a portion that is related to portfolio motives and one related to transactions motives. The latter could then be combined with ordinary transactions balances to form a new transactions-related measure of money along the lines of Tinsley, Garrett, and Friar. ${ }^{23}$ It is not clear, however, that econometric procedures have been refined to the point where the transactions-related portion of such instruments can be reliably separated from the remainder. Moreover, as noted above, to the extent that many financial innovations tend to be part of an ongoing process related to cashmanagement and competitive pressures, new instruments are likely to appear as transactions balances, requiring continued redefinition of money. Alternatively, data on the short-term buffers and cash-management developments could be used to adjust judgmentally the growth of the aggregates. The targeted growth in the monetary aggregates could then be modified to reflect the impact of such developments.

For the mid-1974 to early 1977 period, such ex post judgmental changes would undoubtedly place adjusted growth in $M_{1}$ and $M_{2}$ at rates closer to the predicted values than to the actual values in tables 1 and 2 . A similar change in the current period of apparent weakness would show adjusted growth rates somewhat stronger than the measured growth rates. It is reasonable to assume, therefore, that targeted growth rates of nominal GNP are consistent with somewhat slower growth in current measures of the monetary aggregates than the historical relationships suggest. However, given the unpredictable timing and size of the shifts in $\mathbf{M}_{1}$ demand,

21. This point is elaborated in Tinsley, Garrett, and Friar, "The Measurement of Money Demand." Restricting the techniques to overnight instruments would reduce this problem but not eliminate it. Moreover, if such instruments are included, why not include those maturing in two days? A definitional boundary has to be arbitrarily drawn somewhere, but where?

22. Any excluded instrument having yields and transactions costs similar to those included is likely to have a high elasticity of substitution with included instruments.

23. Tinsley, Garrett, and Friar, "The Measurement of Money Demand." 
it is likely that even the best adjustments will be off the mark. In such an environment, it is more important than ever that policymakers supplement information on monetary aggregates with data on near money and other financial assets, interest rates, and direct indicators of current and future developments in the economy.

\section{APPENDIX}

Appendix table A-1 shows estimated equations for money demand, based on some alternative definitions of the monetary aggregates discussed in the text. 


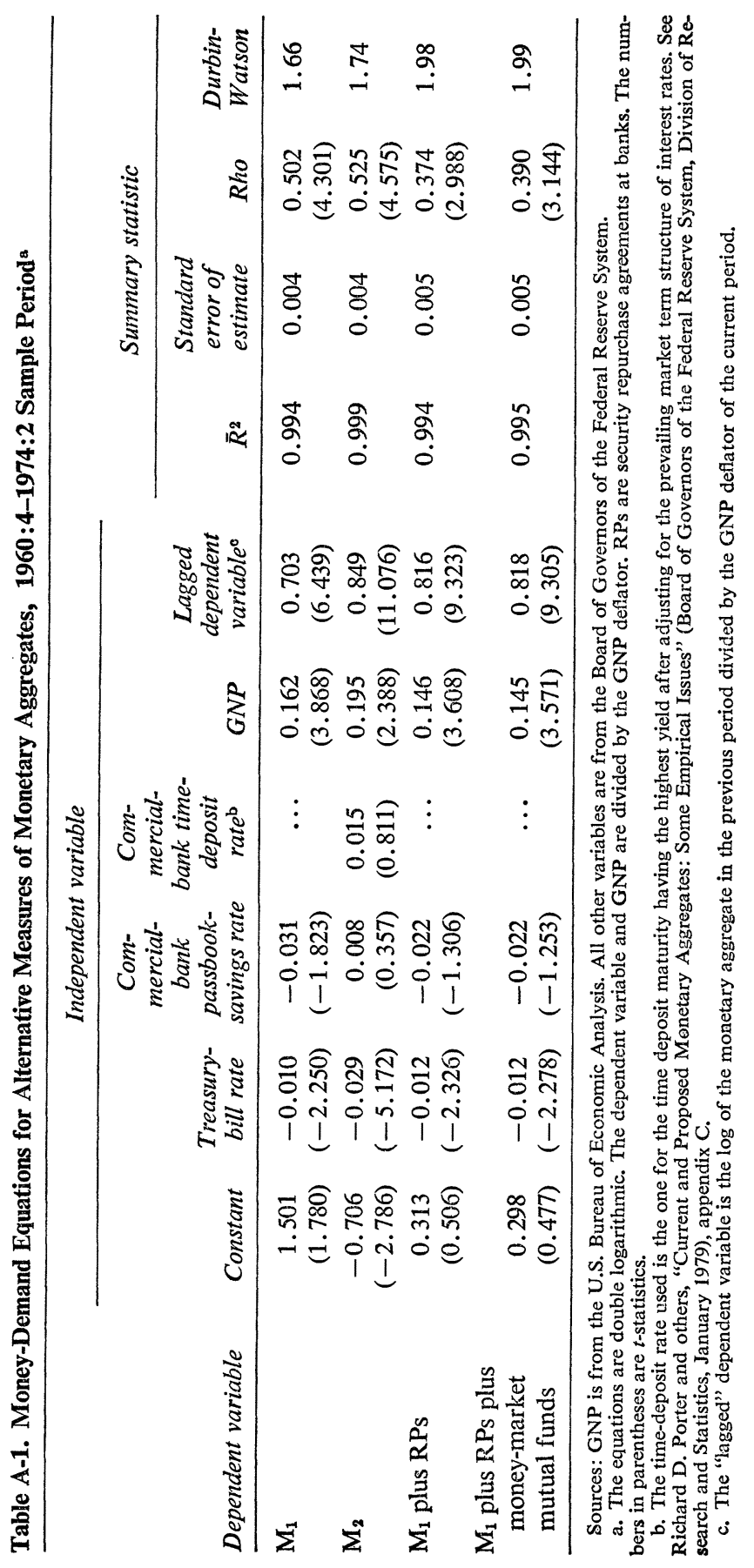

